\title{
sciendo
}

Research Article

(C) 2019 Wongsirasawat et.al. This is an open access article licensed under the Creative Commons Attribution-NonCommercial-NoDerivs License (http://creativecommons.org/licenses/by-nc-nd/3.0/).

\section{Administrator Role Indicators for Encourage Efficiency on Learning Management in School: Confirmatory Factor Analysis}

\author{
Chanchai Wongsirasawat \\ Ph.D. in Vocational Education Administration, Faculty of Education, \\ Valaya Alongkorn Rajabhat University under the Royal Patronage, \\ Pathum Thani, Thailand \\ Phadungchai Pupat
}

Ph.D. in Educational Measurement and Evaluation, Faculty of Industrial Education and Technology, King Mongkut's Institute of Technology Ladkrabang,

Bangkok, Thailand

\section{Sawat Phetchabun}

Director, Horwang School, Bangkok, Thailand

Doi: $10.2478 / \mathrm{mjss}-2019-0058$

\section{Abstract}

The present research was aimed to validate the construct validity of the administrator role indicators for encourage efficiency on learning management in school under the Office of the Basic Education Commission. A stratified random sampling method was used to select a sample of 150 school administrators under the Office of the Basic Education Commission. The research instrument used was a 5 rating scale questionnaire with content validity from 0.60-1.00. The data analyses were first order a confirmatory factor analysis. The results of the study indicated that the administrator role indicators for encourage efficiency on learning management in school under the Office of the Basic Education Commission comprised 15 indicators, is valid and fit to empirical data i.e. Chi-square $=87.675$, degree of freedom $(d f)=76, p$-value $=0.170, \mathrm{GFI}=0.931, \mathrm{AGFI}=0.892$, and $\mathrm{RMSEA}=0.019$.

Keywords: Indicators; Administrator Role; Learning Management

\section{Introduction}

To develop a country within this global context, it must be driven by innovation and creativity, along with the skills necessary for workers within a $21^{\text {st }}$ century period (Reeve, 2016). The $20-Y e a r$ National Strategy is crucial for Thailand to achieve sustainable development and have a clear direction for long-term development, under the vision of the "Stability, Prosperity, and Sustainability". The policy of Thailand 4.0 is one of the significant challenges to education development. To handle this situation, the education system needs serious improvement to produce more productive and highly skilled human resources for the country's ongoing development. Lifelong learning will become more important for providing elderly persons with knowledge to maintain their quality of life (Office of the Education Council, 2017). According to the National Education Act B.E. 2542 (1999) and Amendments (Second National Education Act B.E. 2545 (2002)), the power of administration and management relating to academic matters, budgets, personnel, and general affairs is decentralized to the basic education institutions (Office of the Basic Council, 2003).

The fundamental education administration under the Office of Basic Educational Commission, 
Ministry of Education has duties to provide opportunity to all children to acquire knowledge, skills, morality and ethics and desirable characteristics according to curriculum objectives. The fundamental education management also play role in development of educational system which focuses on participatory development in order to take responsibility on educational quality and standards, and maximizing its benefits (Office of the Basic Education, 2015). Learning management is an important process in education. It is a process of transferring knowledge and experience from teachers to students aiming to enhance students' knowledge and capability. In other words, learning management is a tool to develop students' skills to achieve learning outcomes. The effective learning management will enhance students to gain core knowledge, skills and positive attitude of what they have studied in which they can apply them in other situations or as a foundation for further education. Now, the education problem is an unsolvable issue in the Thai educational system. This is worrisome, especially in terms of the quality of education as, though huge investments have been made in the education budget to improve development, the quality of education seen in Thai students does not match standards (Morjai, Pupat, \& Pimdee, 2018). As a matter of fact, school administrators should be accountable for academic achievement of all children. The Framework of the $21^{\text {st }}$ century skills was included in a draft plan of Thailand's 20-Year National Strategy. This aims to develop learners' skills and prepare people for Thailand 4.0 society, the age of Value-Based economy. Thailand 4.0 society needs the workforce with the $21^{\text {st }}$ century skills in order to lead to sustainable country. It is needed to focus on economic structural reform, research and education reform by working along with network partners (Suvit Maesincee, 2016). Thus, improving school administrators' knowledge, skills, competencies and desired characteristics is an important duty. It is necessary to focus on this matter since education management depends on how capable of school administrators can manage within their own institutions. Therefore, this study focus on analyzing elements and indicators of institution management which follow Thailand's 20-Year National Strategy, Thailand 4.0, National Education Plan, $21^{\text {st }}$ century learning, basic education learning management, management competency for student-based learning, transformative learning, school-based management, participation management and lifelong learning.

Schools in $21^{\text {st }}$ century, school administrators play significant roles in school's management. They have to address the challenges that education faces today through knowledge and new role in this century. Fullan (2001) points out that the school administrators' role has become more overwhelming, more multifaceted, and more fulfilling for those who learn to guide changes. Thus, it is expected that administrators should be expert in management and have leadership skills. Their duties should include building engagement between internal personnel and outside parties, and lead institutions toward goals. Without leadership skills, the administrators may fail as being a leader. According to the study of learning management competency, it says that the significant indicators are knowledge and academic management, education quality improvement, ICT literacy and communication, learning material support for enhancing communication skill and moral building. As a priority, Thailand needs to build a holistic professional development strategy that ensures that school leaders are prepared to effectively implement the basic education curriculum and work toward system-wide education reform goals. The school administration continuously follows up the students' issues and problems, monitors and provides solutions (Faulkner, 2015). School administration is a key factor that policy makers can influence the enhancement of student learning. In recognition of principals' important roles - particularly in driving education reform high-performing jurisdictions are now developing leadership standards and using them to inform school principals' preparation, performance appraisal and ongoing development (OECD/UNESCO. 2016). The challenge is how to reach the stage where every school has achieved at least a quality basic education necessary for their function in society. The school has to be changed; school administers need to provide the frame for the idea needed to create the strategy and tools to help and support other necessary and important thing of school administration that encourage efficiency on learning management in school. Administrator role for encourages efficiency on learning management is an important subject because administrator will provides the teachers and students' opportunities to learn and know the state of a problem that enable them to use all of their skills to solve the problems by developing teaching and learning processes in the classrooms. Therefore, it is essential that school administrators must study and understand different learning processes in 
order to be able to select the most effective learning processes for their students.

For the above, the aforementioned problem situations and concepts, the researcher is interested in studying the administrator role indicators for encourage efficiency on learning management in school: confirmatory factor analysis, to ensure that the generated indicator is consistent with empirical data, which can be beneficial to the management in a school to formulate policies for developing and improving the competency of learning management to accordingly acquire better efficiency.

\section{Purposes of the Study}

This research aims to validate the construct validity of the administrator role indicators for encourage efficiency on learning management in school under the Office of the Basic Education Commission.

The research questions were identified as follows. Do the administrator role indicators for encourage efficiency on learning management in school under the Office of the Basic Education Commission fit to the empirical data?

\section{Conceptual Framework}

In this research, researcher was synthesize administrator role indicators for encourage efficiency learning management from related documents as follows: Thailand's 20-Year National Strategy, Thailand 4.0, National Education Plan (2017-2036), $21^{\text {st }}$ Century Learning, Basic Education Learning Management, Report of Educational Quality Assurance, Research from Office of the Education Council, Management Competency for Student-Based Learning, Transformative Learning, School-Based Management, and Participation Management. After that, approved the quality of administrator role indicators for encourage efficiency on learning management in school using focus group discussions involving experts and stakeholders selected by purposive sampling.

In conclusion, educational leaders and principals may benefit from the results of the study to develop administrator role for encourage efficiency on learning management in schools which consisted of 15 indicators.

\section{Research Hypotheses}

Administrator role indicators for encourage efficiency on learning management in school under the Office of the Basic Education Commission, developed by the researcher, consistent with the empirical data.

\section{Research Methodology}

To validate the construct validity of administrator role indicators for encourage efficiency on learning management in school under the Office of the Basic Education Commission. The research procedures were as follows:

1. Population and Sample; the population were 30,816 administrators in school under the Office of the Basic Education Commission during the academic year of 2018. The sample was selected from the population by stratified random sampling technique. The sample size, using the rule of thumb, was 10 times the number of the parameter in the model (Jackson, 2003). The sample comprised 150 administrators in school under the Office of the Basic Education Commission.

2. Research Instrument; the research instrument focused on administrator role indicators for encourage efficiency on learning management in school under the Office of the Basic Education Commission, as measured by Likert-type scales of 5 levels (Likert, 1967) ( $5=$ the most, $4=$ most, $3=$ moderate, $2=$ less, and $1=$ the least). The questionnaire contained content validity, and the IOC (index of item objective congruence) ranged between $0.60-$ 1.00. (Cronbach, 1990).

3. Data Analysis; for the purpose of this study, administrator role indicators for encourage efficiency on learning management in school under the Office of the Basic Education Commission by first-order confirmatory factor analysis. The Goodness of Fit on Model Measurement was derived from empirical data, considered through Chi-square Statistics, the Goodness of Fit Index (GFI), and Root Mean Square Error of Approximation (RMSEA).These techniques were used to evaluate the Goodness of Fit of the Model that 
fit the empirical data. The lower cut-off value of acceptable fit for Chi-square was significant, while the value of GFI and AGFI were closer to 1.0, and RMSEA was closer to 0 (Schumacker \& Lomax, 2010).

\section{Results}

List of symbols in the research:

$\begin{array}{ll}\text { RMSEA } & \text { represents } \\ \text { GFI } & \text { represents } \\ \text { AGFI } & \text { represents } \\ \text { Role } & \text { represents } \\ \text { (R1) } & \text { represents } \\ \text { (R2) } & \text { represents } \\ \text { (R3) } & \text { represents } \\ \text { (R4) } & \text { represents } \\ \text { (R5) } & \text { represents } \\ \text { (R6) } & \text { represents } \\ \text { (R7) } & \text { represents } \\ \text { (R8) } & \text { represents } \\ \text { (R9) } & \text { represents } \\ \text { (R10) } & \text { represents } \\ \text { (R11) } & \text { represents } \\ \text { (R12) } & \text { represents } \\ \text { (R13) } & \text { represents } \\ \text { (R14) } & \text { represents } \\ \text { (R15) } & \text { represents }\end{array}$

Root Mean Square Error of Approximation

Goodness of Fit Index

Adjusted Goodness of Fit Index

Responsible behavior of school administrators

Curriculum Management

Research for Learning Development

Quality Assurance Development

Supervision, Follow-up and Evaluation

Morale Building

Participative Management

Teacher Development

Instructional Leadership

Transformational Leadership

ICT Literacy

Being Honest

Professional Responsibility

Being Friendly

Strengthening network partners

Create collaboration from network partners

Table 1: Values of Correlation Coefficient of administrator role indicators for encourage efficiency on learning management in school under the Office of the Basic Education Commission.

\begin{tabular}{|c|c|c|c|c|c|c|c|c|c|c|c|c|c|c|c|}
\hline \multirow{2}{*}{$\begin{array}{l}\text { Observed } \\
\text { Variables }\end{array}$} & \multicolumn{15}{|c|}{ Correlation Coefficient } \\
\hline & R1 & $\mathrm{R} 2$ & R3 & $\mathrm{R} 4$ & R5 & R6 & R7 & R8 & R9 & R10 & R11 & R12 & R13 & R14 & R15 \\
\hline R1 & 1.000 & & & & & & & & & & & & & & \\
\hline $\mathrm{R} 2$ & .181 & 1.000 & & & & & & & & & & & & & \\
\hline R3 & .485 & .413 & 1.000 & & & & & & & & & & & & \\
\hline $\mathrm{R} 4$ & .378 & .416 & .511 & 1.000 & & & & & & & & & & & \\
\hline R5 & .383 & .166 & .362 & .275 & 1.000 & & & & & & & & & & \\
\hline $\mathrm{R} 6$ & .459 & .367 & .530 & .345 & .520 & 1.000 & & & & & & & & & \\
\hline R7 & .238 & .385 & .381 & .381 & .504 & .531 & 1.000 & & & & & & & & \\
\hline $\mathrm{R} 8$ & .392 & .224 & .455 & .347 & .476 & .451 & .506 & 1.000 & & & & & & & \\
\hline R9 & .363 & .213 & .393 & .296 & .448 & .495 & .479 & .702 & 1.000 & & & & & & \\
\hline R10 & .223 & .328 & .427 & .296 & .356 & .389 & .325 & .329 & .318 & 1.000 & & & & & \\
\hline R11 & .334 & .158 & .302 & .236 & .620 & .342 & .403 & .490 & .424 & .245 & 1.000 & & & & \\
\hline R12 & .322 & .205 & .316 & .227 & .483 & .390 & .301 & .443 & .493 & .282 & .547 & 1.000 & & & \\
\hline R13 & .265 & .101 & .372 & .264 & .413 & .435 & .428 & .377 & .464 & .320 & .391 & .377 & 1.000 & & \\
\hline R14 & .254 & .273 & .277 & .311 & .196 & .363 & .325 & .120 & .182 & .169 & .226 & .326 & .162 & 1.000 & \\
\hline R15 & .424 & .281 & .524 & .394 & .375 & .466 & .369 & .358 & .379 & .402 & .302 & .380 & .346 & .509 & 1.000 \\
\hline
\end{tabular}

6.1 Results of validity of administrator role indicators for encourage efficiency on learning management in school under the Office of the Basic Education Commission.

Table 1 shows the correlations of 15 observed variables of indicators on administrator role for encourage efficiency on learning management in school under the Office of the Basic Education Commission. The Bartlett's Test of Sphericity tests the hypothesis that the correlation matrix of observed variables is an identity matrix. The analysis results showed that Chi-square $=915.235$, df $=105$, and $p=0.000$, which are different from zero, with a statistical significance level of 0.05 , and also agreed to the analysis results of Kaiser-Meyer-Olkin (KMO) index of Measure of Sampling Adequacy of 0.883 which is closer to 1 . This suggested that the correlation matrix of observed variables is not of identity matrix and strong correlations between variables were found. 


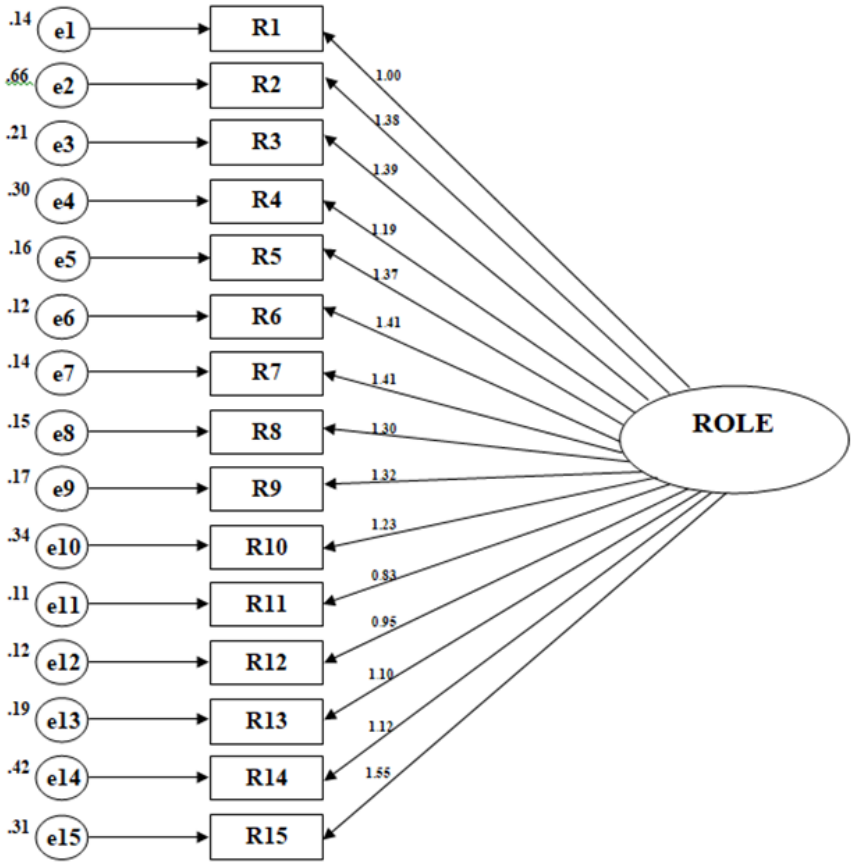

Chi-square $=87.675, \mathrm{df}=76, \mathrm{p}$-value $=0.170, \mathrm{GFI}=0.931, \mathrm{AGFI}=0.892, \mathrm{RMSEA}=0.019$

Figure 1: Model on administrator role indicators.

Figure 1 shows the analysis of the first order confirmatory factor of the administrator role indicators for encourage efficiency on learning management in school under the Office of the Basic Education Commission found that the model was compatible with the empirical data, considering the Chi-square $=87.675$, degree of freedom $=76, \mathrm{p}$-value $=0.170, \mathrm{GFI}=0.931, \mathrm{AGFI}=0.892$, and RMSEA $=0.019$.

\section{Discussion}

The research results of the administrator role indicators for encourage efficiency on learning management in school under the Office of the Basic Education Commission comprised 15 indicators, is valid and fit to empirical data. The result should be trusted since the research had analyzed the famous concepts, theories, and research finding from book, current reports, and journals. Additionally, the research conducted focus group discussions for more information related to administrator role encourage efficiency on learning management in school. The focus group participants who were experienced people jointly discussed intentionally to make the information acceptable. The focus group discussions also helped the researcher get more data, and positive concepts that were trusted and creditable. It was also congruent with the concepts of Kimel (2003) who claims that focus groups can provide concentrated amounts of rich data, in participants' own words, on precisely the topic of interest. Moreover, the sample size was made by the researcher in accordance with the criteria used for multivariable analysis research, together with rule of thumb (Jackson, 2003). The Confirmatory Factor Analysis by using the Coefficient Correlation Matrix of the variables. By using Bartlett's test of Sphericity and the Kaiser-Meyer-Olkin Measure of Sampling Adequacy (KMO), it was found the Bartlett's test value was statistically significant at the .05 level, with the KMO index value of 0.883 , which was close to 1 . From all factors mentioned above helped to support the conclusion that the results from the data analysis of this research model were consistent with the empirical data. 
Furthermore, considering the results of the data analysis, it was found that all indicators, according to the frame work of this research, were statistically significant at the .01 level, with a positive weight factor. This means that, if the school administrator had a high-quality degree according to these indicators. The learning management in schools can increase and improve quality in a better way. From the opinion of experts in the focus group discussions' participants actively share ideas, at present if school administrators have not good development administrator role indicators for encourage efficiency on learning management in school, can't challenge the globalization. As suggested in the research by Schleicher (2012) development of school administrator in positions with program Educational Leadership and Management Program. Which is based on research-based development content developed in accordance with 5 aspects of school administrators; 1) Ability to build relationships and develop people 2) The ability to determine the direction of the school 3) Ability to maintain responsibility for duty 4) Academic leadership ability and 5) Organizational development capabilities. National Association of Secondary School Principals (NASSP) (2013) reported that leadership skills of school administrators in the $21^{\text {st }}$ century that are important and beneficial to school administration to consist of teamwork skill, problem solving skills critical thinking and creativity skill, communication skill, learning innovation skill, digital literacy skills, setting instructional direction skill, sensitivity skill, adjustment skill, and results orientation skill.

In addition, when considering the weight factor of the administrator role indicators for encourage efficiency on learning management in school under the Office of the Basic Education Commission, it was found that the factor with the most important weight was the create collaboration from network partners. It is important to remember that schools needed the participation of stakeholders who got involve with school achievement, especially parent and teacher associations and teachers in charge of student development. This complied with the idea of Ayeni (2010) views the school as an open system that operates a network of inter-relationships among individuals and activities within it, and with the external environment, particularly the stakeholders who formulate the National Policy on Education that stipulates the objectives and operational procedure for the school administration and curriculum implementation. This is congruent with Williams (2002) who said that the organization should collect needs of stakeholders to form its mission and strategies. For this reason, the school administrators should set the policy to reform the creation cooperation from network partners to encourage efficiency on learning management in schools. The new generation school administrators who focus on the future will continuously develop efficiency and manage organization success to reach the high waves of changes in the turbulent world. The research results also point out the importance of the administrator role indicators for encourage efficiency on learning management that they must possess instructional and transformational leaderships. All these require leader was understand transformation and are ready to bring change. Transformational leadership is an important approach to leadership by Bass (1978) who proposed the roles of leadership and followership in order to reach the set target. According to the result, to achieve this efficiency on learning management in schools, school administrators need to understand better about knowledge, ability and skills of teachers that may contribute to the academic success of students. The results are consistent with the research study conducted by Dean (2002) who gave opinion that the school was the place for teachers to learn. Teachers were important human resources to schools who had to be developed in terms of quality in order to serve as a driving force towards school achievement, it was suggested that it is the mission of educational institutions and school to encourage efficiency on learning management in schools and needs to be improved in order to prepare students so that they will possess knowledge, good skills and competencies which corresponding to the skills of the $21^{\text {st }}$ century. Finally, the suitable adaptation of efficiency on learning management in school depending on each school's conditions. School administrators need to provide opportunities, develop teaching processes, learning activities, times, places, and tools for supporting the teachers to implement the school activities effectively on learning management in schools.

The results revealed that the development of administrator role indicators for encourage efficiency on learning management in school under the Office of the Basic Education Commission consisted of 15 indicators. The administrator role indicators for encourage efficiency on learning management in school model was fit to empirical data. 


\section{Implication for Action}

The study results on administrator role indicators for encourage efficiency on learning management in school under the Office of the Basic Education Commission comprised 15 indicators, is valid and fit to empirical data, therefore suggest that school administrators must develop and be able to apply all of role indicators to encourage efficiency on learning management in school.

\section{Further Study}

Further studies should offer the development of competency training course according to the administrator role indicators for encourage efficiency on learning management in school under the Office of the Basic Education Commission to enable the school to have academic strength amid the current changes of the world.

\section{References}

Ayeni. A. J. (2010). Teachers' instructional task performance and principals' supervisory roles as correlates of quality assurance in secondary schools in Ondo State. Doctoral dissertation, Obafemi Awolowo University, Ile-Ife, Nigeria.

Bass, B. M. (1985). Leadership and performance beyond expectations. New York: Free Press.

Cronbach, L. J. (1990). Essentials of Psychological Testing, (5 ${ }^{\text {th }}$ ed.). Harper Collins, New York.

Dean, J. (2002) Implementing performance management a handbook for school. Great Britain: The Cromwell Press.

Faulkner, C. (2015). Women's Experiences of Principalship in two South African high Schools in Multiply Deprived rural areas: A life history Approach. Educational Management Administration \& Leadership, 43(3), 418-432.

Fullan, M. (2001). The new meaning of educational change, $\left(3^{\text {rd }}\right.$ ed.). New York, NY: Teachers College Press.

Jackson, D. L. (2003). Revisiting sample size and number of parameter estimates: Some support for the N:q hypothesis. Structural Equation Modeling, 10, 128-141.

Kimel, M. B. (2003). Focus group methodology. Paper presentation prepared for the FDA Drug Safety \& Risk Management Advisory Committee Meeting, Gaitersburg, Maryland, December 4, 2003.

Likert, R. (1967). The human organization: Its management and values. New York, NY: McGraw-Hill Book.

Morjai, W., Pupat, P., \& Pimdee, P. (2018). Development of Indicators on Automotive Technology Skills of Vocational Diploma Students: A Confirmatory Factor Analysis Model. Mediterranean Journal of Social Sciences, 9(5). Doi : 10.2478/mjss-2018-0152

National Association of Secondary School Principals (NASSP). (2013). Breaking Ranks:

10 Skills for Successful School Leaders. [Online]. Available from :

https://www.nassp.org/Content/158/BR_tenskills_ExSum.pdf [Accessed 1 April 2013].

Office of the Basic Education Commission. (2015). Annual Report 2015. Bangkok, Thailand.

Office of the Education Council. (2017). Education in Thailand. Bangkok:OEC, Prigwan Graphic.

Office of the Education Council. (2003). National Education Act B.E. 2542 (1999) and Amendments (Second National Education Act B.E. 2545 (2002)). Bangkok:

Pimdeekarnpim.

OECD/UNESCO. (2016). Education in Thailand: An OECD-UNESCO Perspective, Reviews of National Policies for Education, OECD Publishing, Paris. http://dx.doi.org/10.1787/9789264259119-en

Reeve, E. M. (2016). $21^{\text {st }}$ century skills needed by students in technical and vocational education and training (TVET). Asian International Journal of Social Sciences, 16(4), 65 - 82. Retrieved from http://tinyurl.com/z97ypfc

Suvit Maesincee. (2016). Thai Economy 4.0: Transforming towards the Value Based Economy, retrieved from https://www.facebook.com/drsuvitpage/posts/1411286459178080

Williams, R. S. (2002). Managing employee performance. London: Thomson Learning, Berkshire House.

Schleicher,A. (2012). Preparing Teachers and Developing School Leaders for the $21^{\text {st }}$ Century.OECD.

Schumacker, R.E., \& Lomax, R.G. (2010). A beginner's guide to structural equation modeling. Routledge, New York. 